\title{
Effect of Alpha-receptor Blocking Drugs and Disodium Cromoglycate on Histamine Hypersensitivity in Bronchial Asthma
}

\author{
JAMES W. KERR, ${ }^{*}$ M.D., F.R.C.P.GLASG., M.R.C.P. ; M. GOVINDARAJ, $†$ M.B., M.R.C.P.GLASG. ; K. R. PATEL, $\ddagger$ M.B., B.S.
}

Cummary: Twenty patients with extrinsic type bronchial asthma are shown to have a significant fall in vital capacity (V.C.) and forced expiratory volume in 1 second (F.E.V.1) after an intravenous infusion of $50 \mu \mathrm{g}$. of histamine dihydrochloride. In 10 of these subjects the fall in V.C. and F.E.V.1 produced by intravenous histamine is inhibited by the alpha-receptor blocking drugs phentolamine and phenoxybenzamine injected before the histamine test. The inhalation of disodium cromoglycate in 10 subjects is also shown to inhibit the fall in V.C. and F.E.V.1 produced by the intravenous infusion of histamine. It is suggested that bronchial smooth muscle in asthmatic subjects has alpha-adrenergic receptor sites, and that a possible mechanism for the action of disodium cromoglycate is that it stabilizes the cell membrane, thereby altering calcium ion transport.

\section{Introduction}

In 1929 Weiss, Robb, and Blumgart reported that intravenously administered histamine produced a fall in ventilatory capacity of asthmatic subjects at dosage levels which did not affect the pulmonary ventilation in normal subjects. This hypersensitivity to histamine of the airways in asthmatic subjects has often been confirmed (Curry, 1946; Dowell, Kerr, and Park, 1966) and has been shown to persist for many years even in the absence of active asthma (Bouhuys et al., 1960).

Certain animal species develop histamine hypersensitivity after an injection of a vaccine prepared from Bordetella pertussis organisms (Parfenjev and Goodline, 1948), and while investigating this phenomenon in the laboratory Fishel, Szentivanyi, and Talmage (1962) observed that in some species histamine hypersensitivity could be produced by the administration of the beta-adrenergic blocking drug dichloroisoproterenol. These authors went on to suggest that the histamine hypersensitivity was the result of a functional imbalance between the two types (alpha and beta) of adrenergic receptor systems, and Szentivanyi (1968) developed this hypothesis into a general theory to explain the atopic abnormality in bronchial asthma. In man the clinical importance of these experimental observations became evident when McNeill (1964) reported that propranolol, a beta-adrenergic receptor blocking drug, caused a fall in ventilatory capacity in asthmatic subjects which was not reversed by isoprenaline. McNeill and Ingram (1966), using a body plethysmograph, further demonstrated increased airways resistance in normal subjects when given propranolol. On the other hand, Zaid and Beall (1966) were unable to show increased bronchial sensitivity to histamine in normal subjects with beta-adrenergic receptor blockade.

Here we report on an investigation designed to assess the relationship of alpha-adrenergic receptors in bronchial smooth muscle to histamine hypersensitivity in patients with bronchial asthma. In addition, it is shown that disodium cromoglycate inhibits the hypersensitivity to histamine of bronchial smooth muscle in patients with asthma.

* Consultant Physician.

† Former Medical Registrar.

$\ddagger$ Medical Registrar

Respiratory Diseases Unit, Western Infirmary and Knightswood Hospital, Glasgow W.3.

\section{Patients and Methods}

Patients with bronchial asthma of the extrinsic type and known to have fully reversible airways obstruction were investigated. These patients all had positive skin tests to inhalant antigens, such as house dust, the house dust mite, and grass pollens. In addition, they all had a blood eosinophilia of at least 700 . cells/cu.mm. The histamine test was carried out in each subject at a time when they had minimal airways obstruction and had not required an oral bronchodilator drug in the preceding 12 hours. Informed consent was obtained for these procedures in every case.

Histamine Test.- The control test was carried out with the patients made comfortable in a sitting position during which baseline levels were determined for the vital capacity (V.C.) and the forced expiratory volume in 1 second (F.E.V.1) in litres, a dry spirometer (Vitalograph) being used. During this period an intravenous infusion of normal saline was set up, and once steady state readings for the vital capacity and F.E.V.1 had been obtained the infusion was switched to a solution of $50 \mu \mathrm{g}$. of histamine dihydrochloride in $200 \mathrm{ml}$. of normal saline. This was administered over a period of 10 to 15 minutes. The vital capacity and F.E.V.1 measurements were continued at regular intervals for $\mathbf{4 0}$ minutes after the infusion of histamine had been completed. For the test infusion the procedure was carried out as above but immediately before the histamine drip was begun $5 \mathrm{mg}$. of phentolamine was injected intravenously into the arm not being used for the infusion. In three patients $10 \mathrm{mg}$. of phenoxybenzamine was administered in $150 \mathrm{ml}$. of normal saline intravenously over a period of two hours before the histamine drip.

Disodium Cromoglycate.-Ten patients had a histamine control test and were then put on disodium cromoglycate (without isoprenaline), three 20-mg. capsules being inhaled daily for a period of two weeks. Following this the histamine test was repeated, each subject inhaling $40 \mathrm{mg}$. of disodium cromoglycate 30 minutes before the test infusion. The investigation was randomized, some patients having the test infusion with phentolamine or disodium cromoglycate carried out first and having the control test repeated at a later date. Patients on disodium cromoglycate were asked to stop this preparation, and one week later the histamine test was repeated. In view of the known prolonged action of phenoxybenzamine this test was always carried out after the control investigation had been completed.

\section{Results}

Alpha-Adrenergic Blocking Drugs.-The results of the control test in which cases Cases 1 to 10 were given $50 \mu \mathrm{g}$. of histamine dihydrochloride intravenously are shown in Table I. The fall in V.C. and F.E.V.1 was observed in all 10 patients and was most pronounced at 10 minutes. There was considerable restitution of both V.C. and F.E.V.1 by 40 minutes (Fig. 1). For the test Cases 1 to 8 received $5 \mathrm{mg}$. of phentolamine intravenously and Cases 8 to $10 \mathrm{had} 10 \mathrm{mg}$. of phenoxybenzamine intravenously before the histamine infusion. The results are shown in Table II. In these patients the fall in V.C. and F.E.V. 1 due to histamine was completely inhibited (Fig. 1). A paired $t$ test shows that there was no significant difference in the V.C. and F.E.V.1 at 0 time and 40 minutes, but at 5, 10, and 20 minutes there was a significant difference in both V.C. and F.E.V.1 when compared with the control test. 


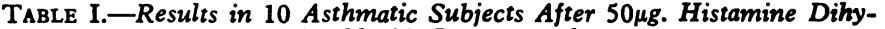
drochloride Intravenously

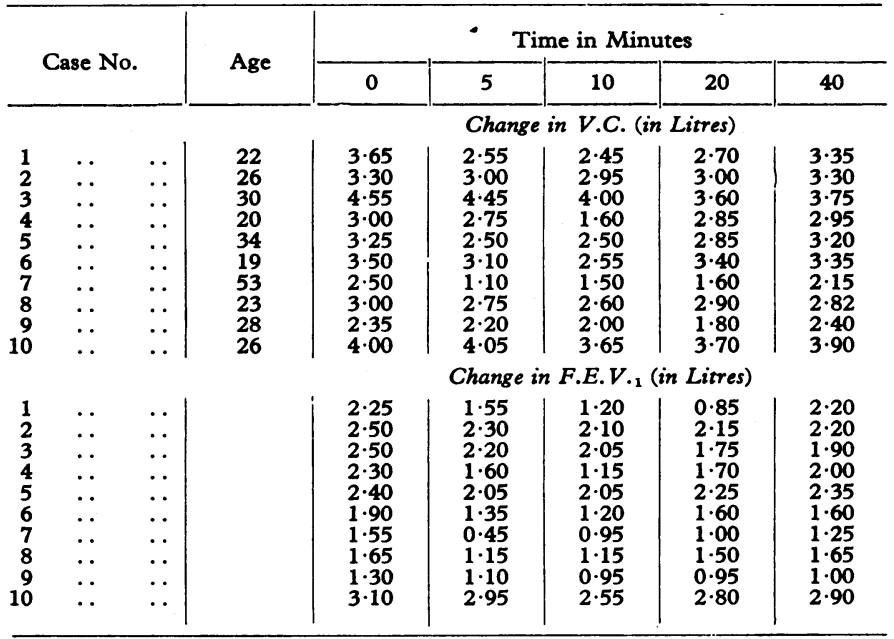

Disodium Cromoglycate.-The results of the control test in which Cases 11 to 20 were given $50 \mu \mathrm{g}$. of histamine dihydrochloride intravenously are shown in Table III. The fall in V.C. and F.E.V.1 was observed in them all and was most pronounced at 20 minutes. There was considerable restitution of both V.C. and F.E.V.1 by 40 minutes (Fig. 2). For the test, Cases 11 to 20 inhaled $40 \mathrm{mg}$. of disodium cromoglycate 30 minutes before the intravenous infusion of histamine. The results are shown in Table IV. In these $\mathbf{1 0}$ patients the fall in V.C. and F.E.V.1 due to histamine was completely inhibited (Fig. 2). A paired $t$ test shows that at 0 time there was no significant difference in the V.C. or F.E.V.1 whereas between 15 and 30 minutes and 10 and 30 minutes for the V.C. and F.E.V.1 respectively there was a significant difference when compared with the control test.

\section{Discussion}

The effect of histamine on smooth muscle may be produced by a direct action of the amine on bronchial smooth muscle or by a delayed reflex action (DeKock, Nadel, Zwi, Colebatch,

TABLE II.-Results in 10 Asthmatic Subjects when $50 \mu g$. Histamine Dihydrochloride is Infused After Phentolamine $5 \mathrm{mg}$. or Phenoxybenzamine $10 \mathrm{mg}$. Intravenously

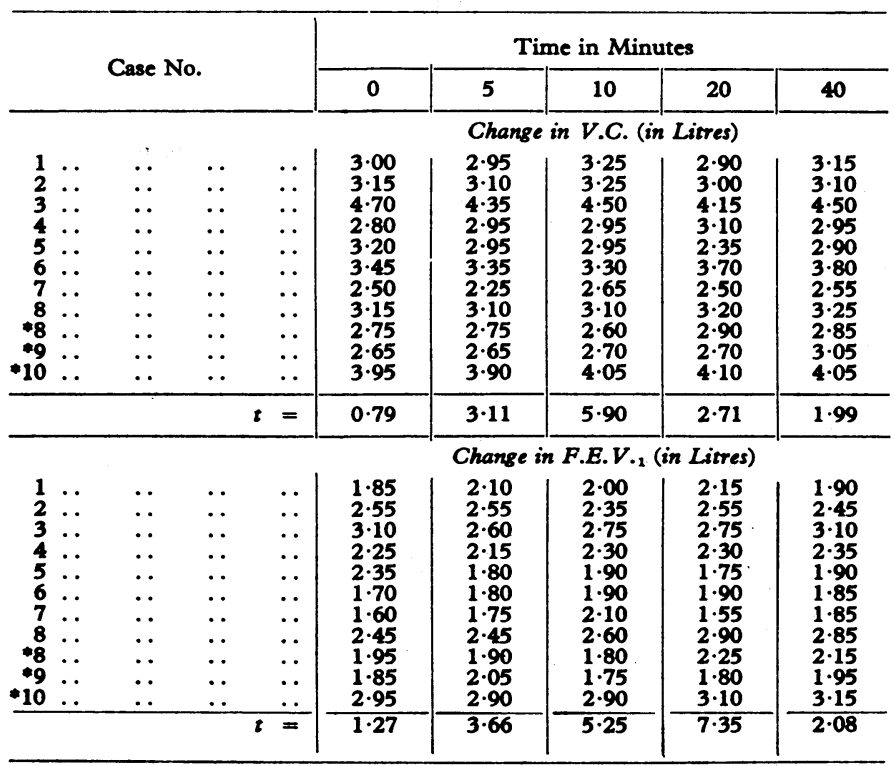

- Subject piren phenoxybenzamine, $\quad 20 \cdot 05=2 \cdot 28 . \quad$ to.01 $=3 \cdot 169$.

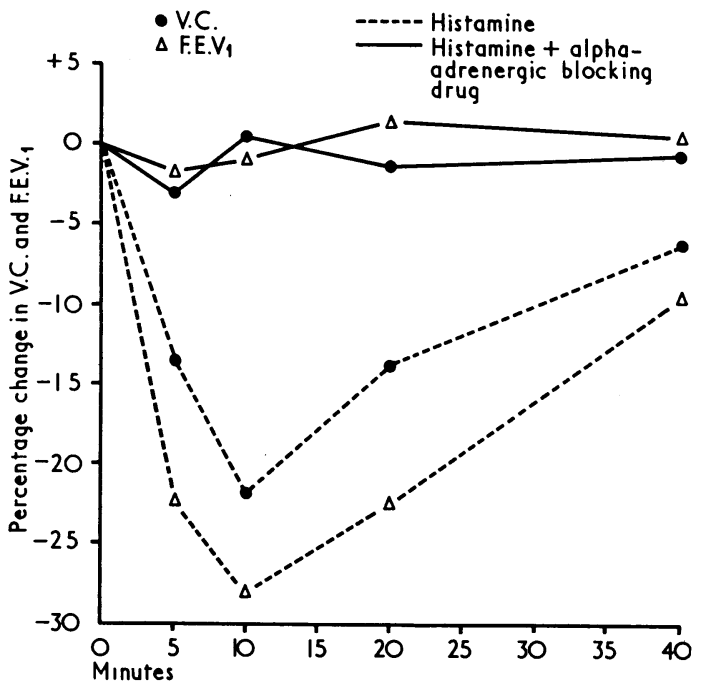

FIG. 1.-Mean fall in V.C. and F.E.V. 1 in 10 subjects after intravenous infusion of $50 \mu \mathrm{g}$. of histamine dihydrochloride. This fall in V.C. and F.E.V.1 is completely inhibited by prior injection of phentolamine or phenoxybenzamine.

TABLE III.-Results in 10 Asthmatic Subjects After $50 \mu g$. Histamine Dihydrochloride Intravenously

\begin{tabular}{|c|c|c|c|c|c|c|c|c|c|c|}
\hline \multirow{2}{*}{$\begin{array}{l}\text { Case } \\
\text { No. }\end{array}$} & \multirow{2}{*}{ Age } & \multicolumn{9}{|c|}{ Time in Minutes } \\
\hline & & 0 & 5 & 10 & 15 & 20 & 25 & 30 & 35 & 40 \\
\hline
\end{tabular}

\begin{tabular}{|c|c|c|c|c|c|c|c|c|c|c|c|}
\hline \multirow[t]{2}{*}{$\begin{array}{l}11 \\
12 \\
13 \\
14 \\
15 \\
16 \\
17 \\
18 \\
19 \\
20\end{array}$} & $\begin{array}{l}. . \\
. \\
. \\
. \\
. \\
. \\
.\end{array}$ & $\begin{array}{l}33 \\
15 \\
28 \\
20 \\
15 \\
31 \\
36 \\
31 \\
13 \\
14\end{array}$ & $\begin{array}{l}3 \cdot 20 \\
3 \cdot 75 \\
2 \cdot 70 \\
2 \cdot 60 \\
3 \cdot 10 \\
3 \cdot 75 \\
4 \cdot 15 \\
3 \cdot 25 \\
2 \cdot 00 \\
4 \cdot 00\end{array}$ & $\begin{array}{l}3 \cdot 20 \\
3 \cdot 10 \\
2 \cdot 70 \\
2 \cdot 40 \\
2 \cdot 75 \\
3 \cdot 10 \\
4 \cdot 10 \\
3 \cdot 10 \\
2 \cdot 00 \\
3 \cdot 90\end{array}$ & $\begin{array}{l}3 \cdot 20 \\
3 \cdot 30 \\
2 \cdot 60 \\
2 \cdot 30 \\
2 \cdot 60 \\
3 \cdot 20 \\
4 \cdot 20 \\
2 \cdot 50 \\
1 \cdot 80 \\
3 \cdot 60\end{array}$ & $\begin{array}{l}2 \cdot 90 \\
3 \cdot 40 \\
2 \cdot 60 \\
2 \cdot 30 \\
2 \cdot 30 \\
3.00 \\
3 \cdot 70 \\
2 \cdot 30 \\
1 \cdot 60 \\
3 \cdot 70\end{array}$ & $\begin{array}{l}2.90 \\
3.50 \\
2.60 \\
2.00 \\
2.30 \\
2.40 \\
3.30 \\
1.90 \\
1.40 \\
3.60\end{array}$ & $\begin{array}{l}2 \cdot 70 \\
3 \cdot 70 \\
2 \cdot 40 \\
1.75 \\
2 \cdot 80 \\
3.30 \\
3.40 \\
2.45 \\
1.75 \\
3.60\end{array}$ & $\begin{array}{l}\mathbf{2} \cdot 80 \\
\mathbf{3} \cdot 50 \\
2 \cdot 30 \\
2 \cdot 30 \\
2 \cdot 95 \\
\mathbf{3} \cdot 20 \\
3.65 \\
2 \cdot 35 \\
2 \cdot 00 \\
\mathbf{3} \cdot 90\end{array}$ & $\begin{array}{l}\mathbf{2} \cdot 80 \\
3 \cdot 70 \\
2 \cdot 30 \\
2 \cdot 20 \\
3 \cdot 20 \\
3 \cdot 25 \\
3 \cdot 80 \\
2 \cdot 45 \\
2 \cdot 00 \\
4 \cdot 00\end{array}$ & $\begin{array}{l}3 \cdot 80 \\
2 \cdot 30 \\
2 \cdot 20 \\
3 \cdot 20 \\
3.35 \\
3.75 \\
2.45 \\
2.00 \\
4 \cdot 00\end{array}$ \\
\hline & & \multicolumn{10}{|c|}{ Change in F.E.V.1 (in Litres) } \\
\hline $\begin{array}{l}11 \\
12 \\
13 \\
14\end{array}$ & $\begin{array}{l}. \\
\ldots \\
\cdots \\
\because \\
\because \\
\cdots \\
.\end{array}$ & & $\begin{array}{l}2 \cdot 25 \\
2 \cdot 40 \\
1.90 \\
1 \cdot 10 \\
2 \cdot 10 \\
2 \cdot 05 \\
2 \cdot 45 \\
1 \cdot 25 \\
1 \cdot 70 \\
2 \cdot 70\end{array}$ & $\begin{array}{l}2.00 \\
1.85 \\
1.90 \\
0.80 \\
1.55 \\
1.90 \\
2.30 \\
1.00 \\
1.55 \\
2.60\end{array}$ & $\begin{array}{l}1.90 \\
1.90 \\
1.80 \\
0.70 \\
1.60 \\
1.90 \\
2.30 \\
0.90 \\
1.20 \\
2.20\end{array}$ & $\begin{array}{l}1 \cdot 80 \\
1.20 \\
1.70 \\
0.90 \\
1.50 \\
1.80 \\
2.20 \\
0.80 \\
1.20 \\
2.00\end{array}$ & $\begin{array}{l}1.85 \\
1.25 \\
1.60 \\
0.90 \\
1.35 \\
1.45 \\
2.10 \\
0.80 \\
1.20 \\
1.95\end{array}$ & $\begin{array}{l}1.90 \\
1.20 \\
1.45 \\
1.00 \\
1.80 \\
1.80 \\
1.90 \\
0.90 \\
1.35 \\
2.70\end{array}$ & $\begin{array}{l}1.75 \\
1.50 \\
1.50 \\
1.00 \\
1.90 \\
1.90 \\
2.00 \\
0.95 \\
1.60 \\
2.70\end{array}$ & $\begin{array}{l}1 \cdot 80 \\
2 \cdot 20 \\
1 \cdot 50 \\
1 \cdot 10 \\
2 \cdot 05 \\
1 \cdot 80 \\
2 \cdot 10 \\
0.90 \\
1 \cdot 70 \\
2 \cdot 70\end{array}$ & $\begin{array}{l}2 \cdot 20 \\
1.50 \\
1 \cdot 10 \\
2 \cdot 00 \\
1 \cdot 65 \\
2 \cdot 10 \\
0.90 \\
1.70 \\
2 \cdot 70\end{array}$ \\
\hline
\end{tabular}

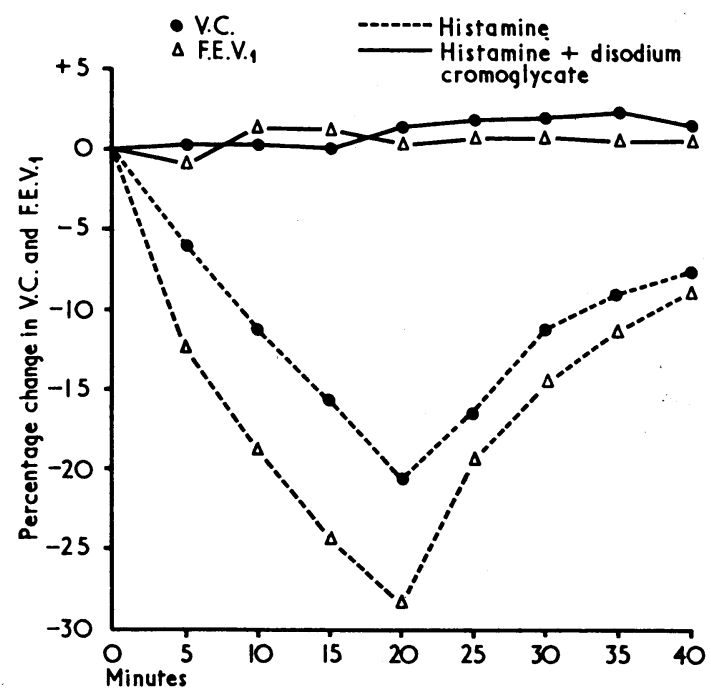

FiG. 2.-Mean fall in V.C. and F.E.V.1 in 10 subjects after intravenous infusion of 50 g. of histamine dihydrachloride. This fall in V.C. and infusion of $50 \mu \mathrm{g}$. of histamine dihydrachloride. This fall in V.C. and F.E.V.1 is completely inhibited by prior 
TABLE IV.-Results in 10 Asthmatic Subjects when $50 \mu g$. Histamine Dihydrochloride Intravenously is Infused after Inhalation of $40 \mathrm{mg}$. Disodium Cromoglycate

\begin{tabular}{|c|c|c|c|c|c|c|c|c|c|c|c|}
\hline \multirow{2}{*}{\multicolumn{3}{|c|}{ Case No. }} & \multicolumn{9}{|c|}{ Time in Minutes } \\
\hline & & & $\mathbf{0}$ & 5 & 10 & 15 & 20 & 25 & 30 & 35 & 40 \\
\hline \multicolumn{12}{|c|}{ Change in V.C. (in Litres) } \\
\hline \multirow[t]{3}{*}{$\begin{array}{l}11 \\
12 \\
13 \\
14 \\
15 \\
16 \\
17 \\
18 \\
19 \\
20\end{array}$} & $\begin{array}{l}\because \\
\because \\
\because \\
\because \\
\because \\
\because \\
\therefore\end{array}$ & $\begin{array}{l}. \\
\cdots \\
\cdots \\
\because \\
\because \\
\because \\
\cdots\end{array}$ & $\begin{array}{l}2.55 \\
2.55 \\
2.80 \\
3.20 \\
3.20 \\
3.80 \\
4.50 \\
3.40 \\
2.20 \\
5.00\end{array}$ & $\begin{array}{l}2 \cdot 60 \\
2 \cdot 60 \\
2 \cdot 80 \\
3 \cdot 20 \\
3 \cdot 20 \\
3 \cdot 80 \\
4 \cdot 50 \\
3 \cdot 35 \\
2 \cdot 20 \\
5 \cdot 20\end{array}$ & $\begin{array}{l}2 \cdot 60 \\
2 \cdot 35 \\
2.90 \\
3 \cdot 30 \\
3 \cdot 20 \\
3 \cdot 80 \\
4 \cdot 60 \\
3 \cdot 25 \\
2 \cdot 20 \\
5 \cdot 10\end{array}$ & $\begin{array}{l}2 \cdot 60 \\
2 \cdot 50 \\
2 \cdot 80 \\
3.20 \\
3.20 \\
3.80 \\
4 \cdot 60 \\
3.25 \\
2.30 \\
5 \cdot 20\end{array}$ & $\begin{array}{l}2 \cdot 60 \\
2 \cdot 70 \\
2 \cdot 80 \\
3 \cdot 20 \\
3 \cdot 20 \\
3 \cdot 85 \\
4 \cdot 50 \\
3 \cdot 30 \\
2 \cdot 30 \\
5 \cdot 10\end{array}$ & $\begin{array}{l}2 \cdot 65 \\
2 \cdot 70 \\
2 \cdot 80 \\
3 \cdot 30 \\
3 \cdot 10 \\
3 \cdot 90 \\
4 \cdot 60 \\
3 \cdot 30 \\
2 \cdot 20 \\
5 \cdot 20\end{array}$ & $\begin{array}{l}2 \cdot 65 \\
2 \cdot 80 \\
2 \cdot 85 \\
3 \cdot 20 \\
3 \cdot 20 \\
3.90 \\
4.50 \\
3.30 \\
2 \cdot 15 \\
5 \cdot 20\end{array}$ & $\begin{array}{l}2 \cdot 70 \\
2 \cdot 70 \\
2 \cdot 90 \\
3 \cdot 30 \\
3 \cdot 30 \\
3 \cdot 90 \\
4 \cdot 60 \\
3 \cdot 30 \\
2 \cdot 20 \\
5 \cdot 20\end{array}$ & $\begin{array}{l}2 \cdot 70 \\
2.85 \\
3 \cdot 30 \\
3 \cdot 25 \\
3 \cdot 85 \\
4.60 \\
3 \cdot 30 \\
2 \cdot 20 \\
5 \cdot 20\end{array}$ \\
\hline & $t$ & $=$ & $0 \cdot 15$ & 1.59 & $1 \cdot 76$ & $2 \cdot 62$ & $9 \cdot 10$ & $2 \cdot 39$ & $2 \cdot 54$ & $2 \cdot 04$ & $1 \cdot 82$ \\
\hline & \multicolumn{11}{|c|}{ Change in F.E.V.1 (in Litres) } \\
\hline $\begin{array}{l}11 \\
12 \\
13 \\
14 \\
15 \\
16 \\
17 \\
18 \\
19 \\
20\end{array}$ & $\begin{array}{l}\ldots \\
\ldots \\
\ldots \\
\ldots \\
\because \\
\cdots \\
\therefore\end{array}$ & $\begin{array}{l}\because \\
\because \\
\because \\
\because \\
\because \\
\because \\
\therefore\end{array}$ & $\begin{array}{l}1.35 \\
1.95 \\
2.15 \\
2.20 \\
1.70 \\
1.80 \\
3.00 \\
1.40 \\
1.70 \\
3.60\end{array}$ & $\begin{array}{l}1.35 \\
1.95 \\
2.20 \\
2.25 \\
1.70 \\
1.80 \\
3.00 \\
1.35 \\
1.70 \\
3.40\end{array}$ & $\begin{array}{l}1.35 \\
2.05 \\
2.20 \\
2.20 \\
1.80 \\
1.80 \\
3.00 \\
1.25 \\
1.80 \\
3.60\end{array}$ & $\begin{array}{l}1.40 \\
1.90 \\
2.30 \\
2.20 \\
1.75 \\
1.85 \\
3.00 \\
1.25 \\
1.80 \\
3.60\end{array}$ & $\begin{array}{l}1 \cdot 30 \\
2 \cdot 00 \\
2 \cdot 20 \\
2 \cdot 20 \\
1 \cdot 80 \\
1 \cdot 75 \\
3 \cdot 00 \\
1 \cdot 25 \\
1 \cdot 80 \\
3 \cdot 70\end{array}$ & $\begin{array}{l}1.45 \\
2.00 \\
2.20 \\
2.30 \\
1.70 \\
1.90 \\
3.00 \\
1.30 \\
1.65 \\
3.55\end{array}$ & $\begin{array}{l}1.30 \\
2.00 \\
2.20 \\
2.30 \\
1.85 \\
1.80 \\
3.00 \\
1.25 \\
1.65 \\
3.70\end{array}$ & $\begin{array}{l}1.45 \\
2.00 \\
2.20 \\
2.35 \\
1.85 \\
1.85 \\
3.05 \\
1.30 \\
1.65 \\
3.60\end{array}$ & $\begin{array}{l}2.00 \\
2.20 \\
2.30 \\
1.80 \\
1.90 \\
3.00 \\
1.30 \\
1.70 \\
3.65\end{array}$ \\
\hline & $t$ & & 0.96 & $1 \cdot 81$ & $2 \cdot 40$ & 3.03 & 3.32 & $2 \cdot 89$ & $2 \cdot 84$ & 1.94 & $2 \cdot 35$ \\
\hline
\end{tabular}

$0.05=2 \cdot 26 . \quad t 0 \cdot 01=3 \cdot 25$

and Olsen, 1966). Our investigation has again confirmed that patients with asthma have a bronchial smooth muscle which is hypersensitive to histamine. We have not been able to show a similar fall in ventilatory capacity to histamine by this method in patients with chronic bronchitis (unpublished observations). The mechanism of this histamine hypersensitivity in bronchial asthma is not clear.

Little attention has been paid to the possibility that bronchial smooth muscle has alpha-adrenergic receptor sites, but alpha-receptor sites do exist on the bronchial smooth muscle of certain animal species (Castro de la Mata, Penna, and Aviado, 1962; Everitt and Cairncross, 1969). Both phentolamine and phenoxybenzamine are classified as alpha-receptor blocking drugs. Phentolamine, which is an imidazole (as is histamine), has a direct effect on the adrenal medulla, releasing noradrenaline. During the test with phentolamine the patients experienced a mild tachycardia but so long as they remained seated during the test there was no fall in blood pressure. It is unlikely that the inhibition of the histamine effect on ventilatory capacity in these patients was mediated via the adrenal medulla. This view would seem to be confirmed by the results obtained with phenoxybenzamine. Though this drug gave rise to tachycardia, hypotension was * not a problem during the test period, as the patients remained at rest. Further, phenoxybenzamine does not have a direct action on the adrenal medulla. Phenoxybenzamine has an antihistamine effect which cannot be dissociated from its alpha-adrenergic blocking activity (Goodman and Gilman, 1965). It is difficult to assess the many pharmacological effects which have been reported due to phentolamine and phenoxybenzamine. Nevertheless, our results suggest that the bronchial smooth muscle of patients with asthma have alpha-adrenergic receptor sites and that blockade of these sites with alpha-receptor antagonists alters the sensitivity of the bronchial smooth muscle to histamine.

Disodium cromoglycate was introduced for the treatment of patients with allergic bronchial asthma by Howell and Altounyan (1967). On inhalation disodium cromoglycate can inhibit the fall in V.C. and F.E.V.1 in patients with allergic asthma when challenged by inhalation of the appropriate antigen (Pepys, Hargreave, Chan, and McCarthy, 1968). This drug has also been shown to inhibit the fall in V.C. and F.E.V. ${ }_{1}$ in exercise-induced asthma (Davies, 1968). On the other hand, disodium cromoglycate has been reported not to affect the histamine resporse of human bronchial smooth muscle (Cox, 1967). We have investigated the effect of this drug on the phenomenon of histamine hypersensitivity in patients with bronchial asthma and have found disodium cromoglycate is a potent inhibitor of the fall in ventilatory capacity produced in these subjects by an intravenous infusion of histamine.

The mechanism by which disodium cromoglycate produces its effect in bronchial asthma remains obscure. The drug inhibits the release of pharmacologically active amines following the antigen-antibody reaction (Cox, 1967). The release of these amines after the antigen-antibody reaction in anaphylaxis is dependent on three factors: calcium, a heat-labile factor, and free sulphydryl groups (Mongar and Schild, 1957; Austen and Humphrey, 1961). Though in some animal species intravenous disodium cromoglycate does give rise to profound reflex cardiovascular changes (Cox, 1967), it is unlikely that disodium cromoglycate acts as an alpha-receptor blocking drug as: cardiovascular effects have not been reported in man.

The alpha- and beta-adrenergic receptors are believed to control the ionized calcium concentration in the environment of the contractile protein of the myofibrils (Filo, Bohr, and Ruegg, 1965; Bohr, 1967), and the histamine response of smooth muscle is dependent on the concentration of ionized calcium (Daniel, 1964). It can therefore be postulated that beta-receptor blocking drugs by increasing the ionized calcium of smooth muscle fibrils increase the histamine response, and that the alpha-receptor blocking drugs by lowering the ionized calcium inhibit the histamine response of bronchial smooth muscle. One explanation of our observations is that disodium cromoglycate stabilizes the cell membrane and this alters calcium ion transport. Such an effect would explain both the inhibition of amine release after the antigenantibody reaction and the inhibition of histamine hypersensitivity of bronchial smooth muscle affected by this drug. Further investigation of the mechanism of action of disodium cromoglycate should lead to a better understanding of the nature of bronchial asthma.

\section{REFERENCES}

Austen. K. F., and Humphrey, J. H. (1961). fournal of Physiology, 158, 36P.

Bohr, D. F. (1967). Annals of the New York Academy of Sciences, 139 799.

Bouhuys, A., et al. (1960). Clinical Science, 19, 79.

Castro de la Mata, R., Penna, M., and Aviado, D. M. (1962). fournal of Pharmacology and Experimental Therapeutics, 135, 197.

Cox, J. S. G. (1967). Nature, 216, 1328.

Curry, J. J. (1946). Fournal of Clinical Investigation, 25, 785.

Daniel, E. E. (1964). Annual Review of Pharmacology, 189.

Davies, S. E. (1968). British Medical foumal, 3, 593.

DeKock, M. A., Nadel, J. A., Zwi, S., Colebatch, H. J. H., and Olsen, C. R. (1966) fournal of Applied Physiology, 21, i85.

Dowell, R. C., Kerr, J. W., and Park, V. A. (1966). Fourmal of Allergy, 38, 290.

Everitt, B. J., and Cairncross, K. D. (1969). Fournal of Pharmacy and Pharmacology, 21, 97.

Filo, R. S., Bohr, D. F., and Ruegg, J. C. (1965). Science, 147, 1581.

Fishel, C. W., Szentivanyi, A., and Talmage, D. W. (1962). foumal of Immunology, 89, 8 .

Goodman, L. S., and Gilman, A. (editors) (1965). The Pharmacological Basis of Therapeutics, 3td ed. New York, Macmillan.

Howell, J. B. L., Altounyan, R. E. C. (1967). Lancet, 2, 539.

McNeill, R. S. (1964). Lancet, 2, 1101.

McNeill, R. S., and Ingram, C. G. (1966). American fournal of Cardiology, 18, 473.

Mongar, J. L., and Schild, H. O. (1957). Fournal of Physiology, 135, 301 .

Parfenjev, I. A., and Goodline, M. A. (1948). Fournal of Pharmacology and Experimental Therapeutics, 92, 411.

Pepys, J., Hargreave, F. E., Chan, M., and McCarthy, D. S. (1968) Lancet, 2, 134.

Szentivanyi, A. (1968). foumal of Allergy, 42, 203.

Weiss, S., Robb, G. P., and Blumgart, H. C. (1929). American Heart fournal, 4, 664.

Zaid, G., and Beall, G. N. (1966). New England fournal of Medicine, $275,580$. 